\title{
Studies on Microtuberization of Five Potato Genotypes
}

\author{
M. M. Khalil, A. M. H. Abd El Aal and M. M. Samy \\ Potato and Vegetatively Propagated Vegetables Department, Horticulture \\ Research Institute, Agricultural Research Centre,Cairo, Egypt.
}

\begin{abstract}
M
ATERIALS of in vitro culture are the first step in most seed potato programs worldwide. Microtubers are considerable tool for implementation of a national seed potato production system in countries lacking isolated high cool latitude and vector free areas for seed potato production. The current study investigates microtuber production ability of 5 genotypes imported from CIP (International Potato Center, Peru) comparing with Diamant variety. Also, studied the impact microtuberization agent $(80 \mathrm{~g} / \mathrm{l}$ sucrose, $5 \mathrm{mg} / \mathrm{l}$ benzyladenine or 500 $\mathrm{mg} / \mathrm{l}$ Chlorocholine chloride) added to MS medium on in vitro microtuberization. Significant differences recorded between genotypes in microtuber weight and number. Unica and Costanera yielded the highest microtubers weight, number and average microtuber weight. The best media for microtuberization was MS supplied with $80 \mathrm{~g}$ sucrose. As a conclusion it is recommended to use elevated sucrose for microtubers production of Unica, Costanera, Yayla Kizi and Meva genotypes.
\end{abstract}

Keywords: Potato, Microtuberization, CIP, Genotypes.

\section{Introduction}

Potato is one of the most important vegetable crops in Egypt. Potato has a crucial part of the exported crops. However, the cost of seeds concern about more than halve the cultivation costs especially in summer season which cultured with imported seeds. Potato propagated by vegetative methods which transmit diseases and pests from generation to another causing the degeneration of seed quality (Struik and Wiersema, 2012). Around the world the means of in vitro culture and micropropagation is the milestone in potato seed production programmes (Ranalli, 1997, Allhloowalia, 1999, Struik \& Wiersema, 2012 and Kawakami et al., 2015). Minituber production in greenhouses is the intermediate step between in vitro multiplication and the normal seed in field. Use of in vitro plantlets produced from nodal cutting is the popular way for production of minituber in greenhouses (Struik, 2007). Microtubers are more vigorous, easy to store and easier to handle comparing with in vitro plantlets (Seabrook \& Coleman, 1988 and McCown\& Joyce, 1991). Recently, many researches compared the performance of microtubers with traditional potato seed tubers and minitubers (Struik \& Lommen, 1999, Wróbel, 2015 and Srivastava,
2015). Furthermore, microtubers is used in potato seed production in many countries they improved self-sufficiency, reduce number of field generation and reduce disease frequency in the final product (Donnelly et al., 2003). Microtubers are produced in vitro in a wide range of different growing systems with varying environment, media constituents, and storage intervals. Many of the interactions between growth parameters in vitro and subsequent productivity appear to be genotype specific (Donnelly et al., 2003).

The current study investigates the microtuberization of five CIP genotypes i.e., Costanera, Meva, Sissay, Unica and Yayla Kizi with different characteristics (Table 1). Costanera and Unica genotype has advantage of adaptability to high temperature which could be an advantage for early planting in august in autumn cultivation under Egyptian conditions. Furthermore, all the tested cultivars have high content of tuber dry matter which of great importance for processing industry. Moreover, the five genotypes are moderately resistance (Costanera, Sissay, Unica and Yayla Kizi) or resistance (Meva) to late blight. 


\section{Materials and Methods}

The current study was conducted in Vegetable Crops Research Departments Tissue Culture Laboratory in Dokii (2015 / 2016). In vitro micropropagated explants of five genotypes i.e., Costanera, Meva, Sissay, Unica and Yayla Kizi (Table 1) imported from international Potato Center (CIP), Peru in addition to Diamant variety plantlets were the source of single node cuttings explants used in the study. The used media for multiplication was MS (Murashige and Skoog, 1962) salts and vitamins media (Cassion Laboratories Inc. USA) supplemented with $10 \mathrm{mg} / 1$ Adenine sulfate, $5 \mathrm{mg} / \mathrm{l}$ calcium pantothenate, 30 $\mathrm{g} / 1$ sucrose and $7 \mathrm{~g} / \mathrm{l}$ agar. The $\mathrm{pH}$ was adjusted to 5.7 before autoclaving at $1.45 \mathrm{Kg} / \mathrm{cm}^{2}$ for 20 min. Microtuberization behavior of the imported genotypes comparing with Diamant was tested using nodal cutting sunder the effect of various additives (microtuberization agents) i.e. sucrose, benzyladenine (BA), Chlorocholine chloride (CCC) or sucrose + BA + CCC to MS nutrient media. Cultures were incubated under 16 hour light at $23^{\circ} \mathrm{C}$. The experiment statistical design was factorial analysis in complete randomized design. Each treatmenten closed 4 replicates each one contained 5 jars. 5 nodal cuttings were cultured per jar ( $500 \mathrm{~g}$ jar containing $50 \mathrm{ml}$ media). Data of microtuberization ratio, microtuber number and weight were collected after 8 weeks. Data were submitted to ANOVA and treatment means were compared using multiple comparison tests at $5 \%$ level of probability using Statistix 10 software.

TABLE 1. Characteristics of 5 CIP genotypes used in the study*

\begin{tabular}{lcccccc}
\hline Name & Origin & $\begin{array}{c}\text { Late blight } \\
\text { resistance }\end{array}$ & $\begin{array}{c}\text { Growing period } \\
\text { (days) }\end{array}$ & Shape & $\begin{array}{c}\text { Dry matter } \\
(\mathbf{\%})\end{array}$ & Adaptation \\
\hline Costanera & Peru & $\begin{array}{c}\text { Moderately } \\
\text { Resistance }\end{array}$ & 90 & Oblong & $23 \%$ & $\begin{array}{c}\text { Tropical- subtropical to } \\
\text { temperate }\end{array}$ \\
\hline Meva & Madagascar & Resistance & 90 & Oblong & $23 \%$ & $\begin{array}{c}\text { Cool, warm and } \\
\text { temperate }\end{array}$ \\
\hline Sissay & Ethiopia & $\begin{array}{c}\text { Moderately } \\
\text { Resistance }\end{array}$ & 90 & Ovoid & $19 \%$ & Cool tropical \\
\hline Unica & Peru & $\begin{array}{c}\text { Moderately } \\
\text { Resistance }\end{array}$ & $90-120$ & Oblong & $20 \%$ & $\begin{array}{c}\text { Tropical and sub-tropical } \\
\text { to temperate }\end{array}$ \\
\hline Yayla Kizi & Turkey & $\begin{array}{l}\text { Moderately } \\
\text { Resistance }\end{array}$ & $90-120$ & Oblong & $23 \%$ & Cool tropics \\
\hline
\end{tabular}

* CIP catalogue of potato varieties (2014)

\section{Results and Discussion}

The obtained results (Fig. 1, Fig.2-a, b, and Table 2) showed a significant differences between genotypes in microtuberization. Unica and Costanera gave the highest microtuberization ratio and microtuber weight per jar. In the second place came Diamant and Yayla Kizi. However, the lowest microtuberization ratio and average microtuber weight produced by Meva and Sissay. The different microtuberization agents caused significant differences in microtuberization ratio and microtuber weight per container (Fig 3-a andb). The media containing sucrose without growth regulators produced the uppermost microtuberization ratio and microtuber weight per jar followed by the media contained sucrose plus $\mathrm{BA}$ and $\mathrm{CCC}$ media. On the other hand, the lowest microtuber weight per jar resulted when media contained CCC or BA alone. Data presented in Table 2 show significant effects for the interaction between varieties and microtuberization agent.

Egypt. J. Hort. Vol. 44, No. 1 (2017)
According to average tuber number per jar the genotypes differed significantly (Fig 2-c). Unica yielded the highest average tuber number per jar followed by Costanera. Another time Sissay recorded the lowest average microtuber number per jar. Moreover, the effect of microtuberization agent on average tuber number was significant (Fig. 3-c). The treatments which contained sucrose or CCC alone or with BA gave higher tuber number per jar than BA alone. The interaction between the two studied factors was significant with the highest average tuber number per jar in Unica on media containing CCC alone, sucrose alone or sucrose plus CCC and BA as well as Costanera on media containing $\mathrm{CCC}$ alone as microtuberization agent (Table 2).

Significant differences were recorded between the different genotypes in average microtuber weight (Fig.2.d). Costanera produced the heaviest microtubers followed by Unica. The lowest average microtuber weight was obtained in Meva. Concerning the microtuberization agent sucrose alone resulted in the highest values of average 
microtuber weight followed by treatments contained sucrose, CCC and CCC together in the same media (Fig. 3-d). On the other hand, $\mathrm{BA}$ or $\mathrm{CCC}$ as sole microtuberization agent recorded the lowest values of average microtuber weight. The interaction between genotypes and
Microtuberization agent on average microtuber weight was significant (Table 2). The maximum average tuber weight was obtained in Unica on media containing sucrose alone.

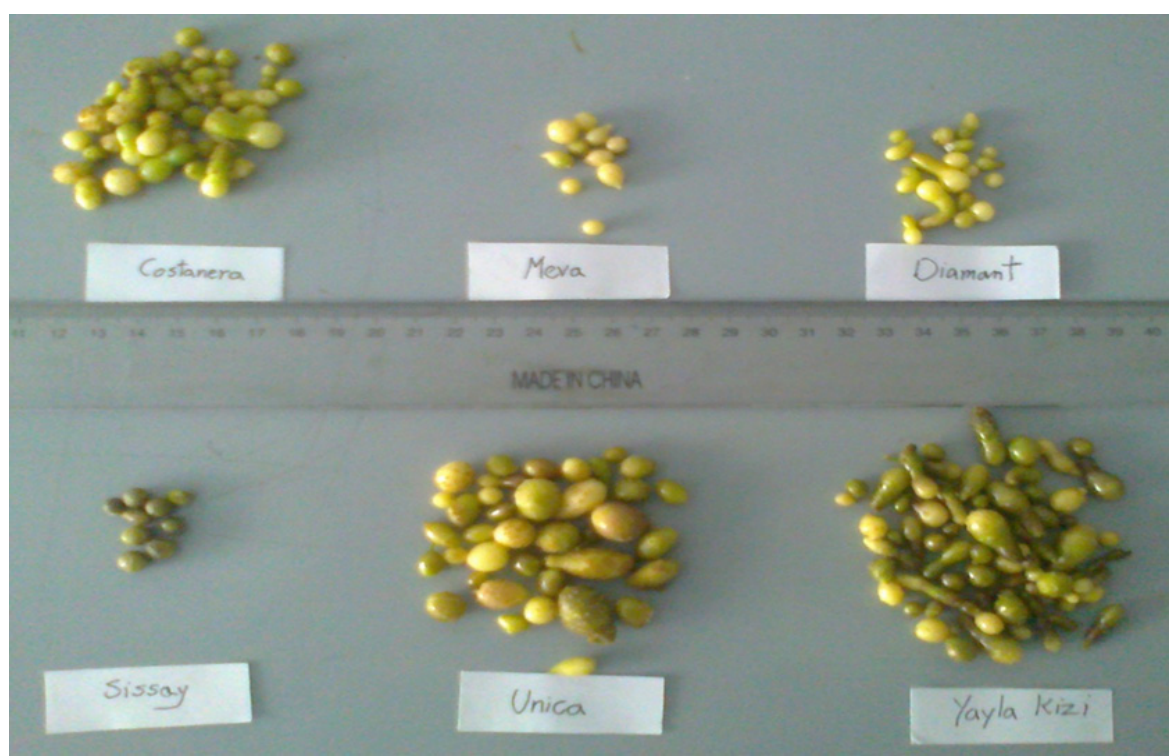

Fig. 1. Microtubers of 5 CIP genotypes comparing with Diamant formed after 8 weeks from culture in vitro on media containing sucrose only as microtuberization agent.

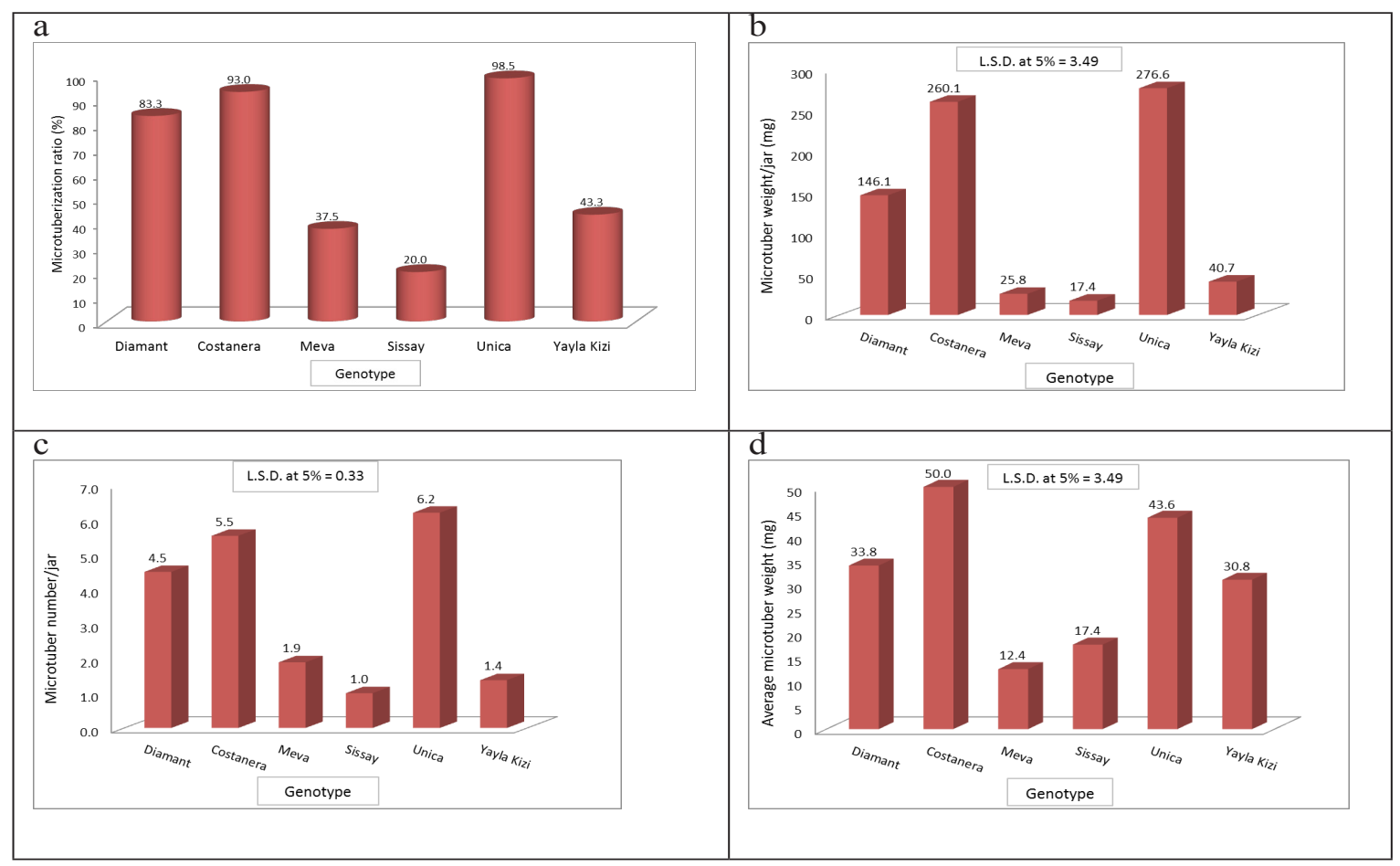

Fig. 2. Main effects of genotypes $(a, b, c, d)$ on microtuberization ratio, microtuber weight per jar, number and average micotuber weight after 8 weeks from culture. 
TABLE 2. Effect of interaction between genotype and microtuberization agent on microtuber average weight jar, number and microtuber weight after 8 weeks from culture in vitro.

\begin{tabular}{|c|c|c|c|c|}
\hline Genotype & $\begin{array}{c}\text { Microtuberization } \\
\text { agent }\end{array}$ & $\begin{array}{c}\text { Microtuber weight/ } \\
\text { jar (mg) }\end{array}$ & $\begin{array}{c}\text { Microtuber number/ } \\
\text { jar }\end{array}$ & $\begin{array}{c}\text { Average } \\
\text { microtuber weight } \\
(\mathrm{mg})\end{array}$ \\
\hline \multirow[t]{4}{*}{ Diamant } & Sucrose & 275.8 & 4.7 & 61.8 \\
\hline & $\mathrm{BA}^{*}$ & 60.8 & 3.0 & 23.0 \\
\hline & $\mathrm{CCC}^{*}$ & 118.3 & 4.2 & 28.8 \\
\hline & Sucrose $+\mathrm{BA}+\mathrm{CCC}$ & 129.5 & 6.1 & 21.5 \\
\hline \multirow[t]{4}{*}{ Costanera } & Sucrose & 306.0 & 5.7 & 57.0 \\
\hline & BA & 200.5 & 4.0 & 53.0 \\
\hline & $\mathrm{CCC}$ & 228.3 & 6.7 & 34.8 \\
\hline & Sucrose $+B A+C C C$ & 305.5 & 5.8 & 55.3 \\
\hline \multirow[t]{4}{*}{ Meva } & Sucrose & 58.8 & 3.4 & 18.3 \\
\hline & BA & 13.8 & 1.4 & 10.0 \\
\hline & $\mathrm{CCC}$ & 14.3 & 1.4 & 9.8 \\
\hline & Sucrose $+\mathrm{BA}+\mathrm{CCC}$ & 16.3 & 1.4 & 11.5 \\
\hline \multirow[t]{4}{*}{ Sissay } & Sucrose & 22.3 & 1.0 & 22.3 \\
\hline & BA & 12.8 & 1.0 & 12.8 \\
\hline & $\mathrm{CCC}$ & 15.8 & 1.0 & 15.8 \\
\hline & Sucrose $+B A+C C C$ & 19.0 & 1.0 & 19.0 \\
\hline \multirow[t]{4}{*}{ Unica } & Sucrose & 575.3 & 6.4 & 89.5 \\
\hline & BA & 104.0 & 4.8 & 21.8 \\
\hline & $\mathrm{CCC}$ & 199.8 & 7.1 & 28.3 \\
\hline & Sucrose+BA+ CCC & 227.5 & 6.5 & 35.0 \\
\hline \multirow[t]{4}{*}{ Yayla Kizi } & Sucrose & 64.3 & 1.4 & 50.5 \\
\hline & BA & 27.5 & 1.3 & 21.0 \\
\hline & $\mathrm{CCC}$ & 29.3 & 1.4 & 21.5 \\
\hline & Sucrose $+\mathrm{BA}+\mathrm{CCC}$ & 41.8 & 1.4 & 30.3 \\
\hline $\operatorname{LSD}(p 0.05)$ & & 41.59 & 0.67 & 6.97 \\
\hline
\end{tabular}

The differences between studied genotypes related to its genetic makeup since they are different in origin and adaptability. The obtained data are in accordance with Gopal and Minocha (1997) who found that significant genotypic differences for different characters in microtuber and normal seed tubers. The obtained effects of high sucrose concentrations on microtuberization are in line with those obtained by Garner and Blake (1989) and EL-Sharabasy et al. (2012). Also Wang and $\mathrm{Hu}$ (1982) recommended the addition of $80 \%$ sucrose to media contain BA to enhance microtuberization. In this respect, Khuri and Moorby (1995) suggested that sucrose play major role in microtuberization, hence high sucrose trigger tuber initiation while high Egypt. J. Hort. Vol. 44, No. 1 (2017) osmolality insure starch deposition. Furthermore, $\mathrm{Xu}$ et al. (1998) stated that sucrose regulates tuber formation by changing gibberellin level. According to $\mathrm{BA}$ and $\mathrm{CCC}$ effects on the reduction of microtuber weight obtained results are agreed with those obtained by Harvey et al. (1991) who stated that CCC caused reduction in microtuber fresh weight. Furthermore, Leclerc et al. (1994) stated that $\mathrm{CCC}$ and $\mathrm{BA}$ reduced fresh weight and number of microtubers. Although, other literatures indicate that $\mathrm{CCC}$ reinforce $\mathrm{BA}$ effect leading to earlier microtuberization (Hussey \& Stacey, 1984 and Protacio \& Flores, 1992) and larger microtubers (Protacio and Flores, 1992). This could be attributed to the difference in light treatment since we used 16h light/ $8 \mathrm{~h}$ dark while Hussey and Stacey (1984) indicated that BA effect 
was more pronounce in short (8h) than long day (24h). On the other side, El-Sawy and El-Sherif (2014) indicated that microtuberization was better on media with $16 \mu \mathrm{M}$ kinetin $6 \%$ sucrose than which contain $8 \%$ sucrose and other growth regulators combinations. Also, El-Sawy and
Girgis (2015) obtained the highest microtubers number and weight on media which contain 2 $\mathrm{mg} / \mathrm{l} \mathrm{BA}, 2 \mathrm{mg} / \mathrm{l} \mathrm{NAA}$, and $100 \mathrm{mg} / \mathrm{l} \mathrm{CCC}$.

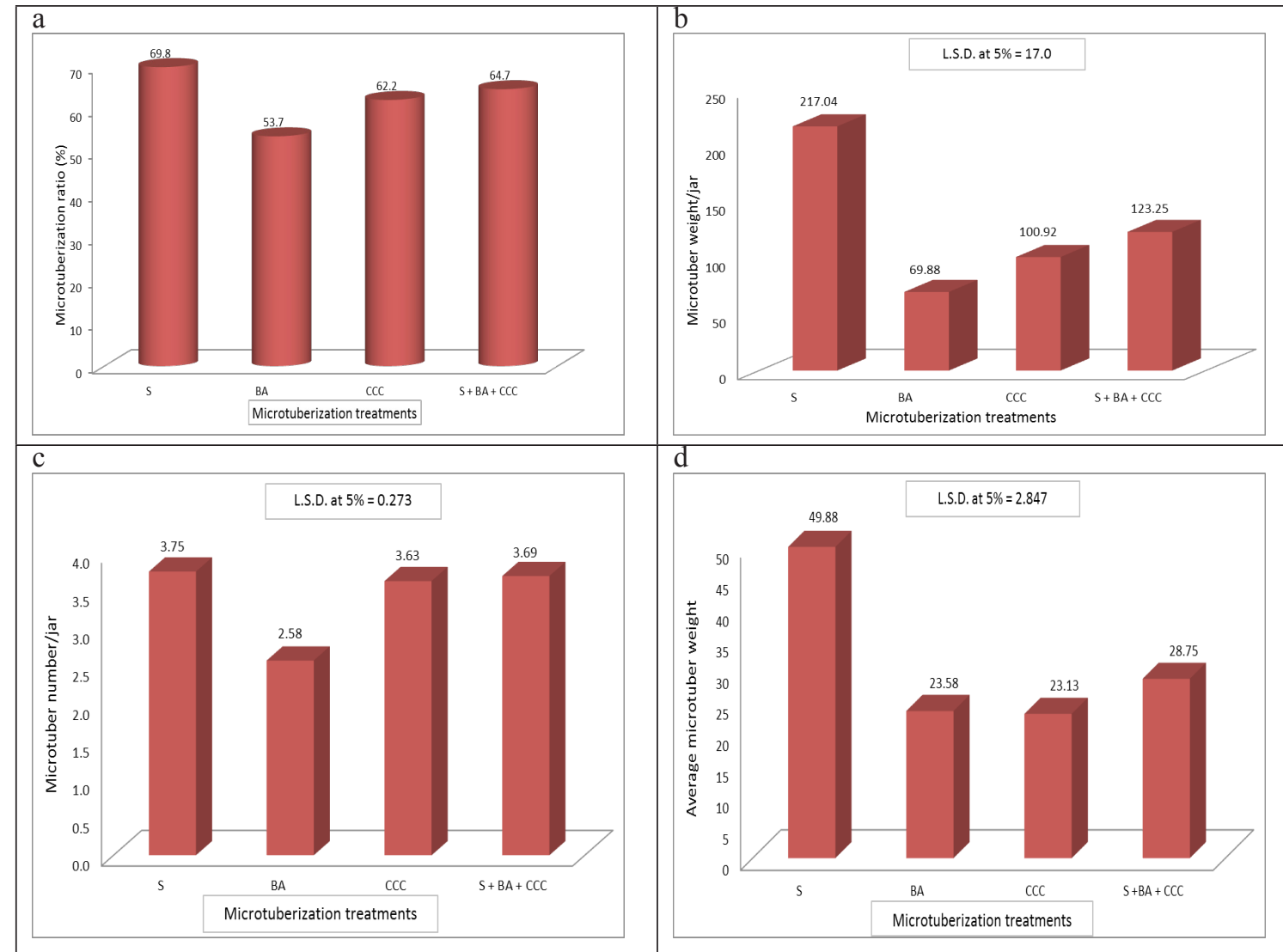

Fig.3. Main effects of microtuberization agent $(\mathbf{a}, \mathbf{b}, \mathbf{c}, \mathbf{d})$ on microtuberization ratio, microtuber weight per jar, number and average micotuber weight after 8 weeks from culture.

The difference in the microtuberization rate and weight could be resulted from the difference in genotypes used, the growth conditions (light and temperature) or the physiological age and type explant. Concerning the interaction between genotypes and microtuberization agent in the same line based on the significant interactions between twenty two potato genotype and different in vitro cultural condition Gopal et al. (1998) stated that it is important to develop genotype specific protocols for optimum microtuberization. In conclusion, CIP genotypes Unica, Costanera, Yayla Kizi and Meva could be micropropagated successfully by microtuber production on MS media with $80 \%$ sucrose without growth regulators. The obtained microtubers could be a reliable material for a national pre-basic potato seed program.

\section{References}

Allhloowalia, B.S. (1999) Production of miniseed tubers using a modular system of plant micropropagation. Potato Res., 42, 569 - 575.

Protacio, C.M. and Flores, H.E. (1992)The role of polyamines in potato tuber formation. In Vitro Cell, Dev. Biol., 28, 81-86.

CIP Catalogue (2014) http://cipotato.org/publications/ catalogue-of-potato-varieties-and-advancedclones-2014

Donnelly, D.J., Coleman, W.K., Coleman,S.E. (2003) Potato microtuber production and performance: $A$ review. Am. J. Potato Res., 80, 103-115. 
El-Sawy, A.M. and El-Sherif, M.H. (2014) A novel in vitro hydroponics culture system for potato (Solanumtubersum L) microtuber production.J. Appl. Sci. Res., 10, 211-217.

El-Sawy, A.M. and Girgis, N.D. (2015) Effect of Gelling Agent on in vitro tuberization of potato. American-Eurasian J. Agric. \& Environ. Sci., 15 (10), 1934-1939.

El-Sharabasy, S.F., El-Sharnouby, M.E. and Zahran, A.A. (2012) Effect of potassium and sucrose concentrations on the production of potato microtubers through tissue culture. Arab J. Nucl. Sci. App., 45 (2), 561-567.

Garner, N. and Blake, J. (1989)Theinduction and development of potato microtubers in vitro on media free of growth regulating substances.Ann. Bot., 63, 663-674.

Gopal, J. and Minocha, J.L. (1997)Effectiveness of selection at microtuber crop level in potato. J. Plant Breeding, 116, 293-295.

Gopal, J., Minocha, J.L. and Dhaliwal, H.S. (1998) Microtuberization in potato (Solanum tuberosum L.). Plant Cell Rep., 17, 794-798.

Harvey, B.M.R., Crothers, S.H., Evans,N.E. and Selby,C. (1991) The use of growth retardants to improve microtuber formation bypotato (Solanum tuberosum). Plant Cell, Tiss. Org., 27, 59-64.

Hussey, G. and Stacey, N.J. (1984) Factors affecting the formation of in vitro tubers of potato (Solanum tuberosum L.). Ann. Bot., 53, 565-578.

Kawakami, T., Oohori, H. and Tajima, K. (2015)Seed potato production system in Japan, starting from foundation seed of potato. Breeding Sci., 65, 17-25.

Khuri, S. and Moorby, J. (1995) Investigation into the role of sucrose in potato cv. Estima microtuber production in vitro. Annal. Bot., 75, 295-303.

Leclerc, Y., Donnelly, D.J. and Seabrook, J.E.A. (1994) Microtuberization of layered shoots and nodal cuttings of potato: The influence of growth regulators and incubation periods. Plant Cell Tiss. Org., 37, 113-120.
McCown, B. and Joyce, P. (1991) Automated propagation of microtubers of potato. In: Scaleup and Automation in Plant Propagation,I.K. Vasil (Ed.), pp. 95-110. Academic Press, San Diego.

Murashige, T. and Skoog, F. (1962) A revised medium for rapid growth and bio assays with tobacco tissue cultures. Physiol. Plantarum, 15, 473-479.

Ranalli, P. (1997) Innovative propagation methods in seed tuber multiplication programmes. Potato Res., 40, 439-453.

Seabrook, J.E.A. and Coleman,S. (1988) Guidelines for shipping in vitro potato plantlets. Am. Potato J., 65, 301-308.

Srivastava, A.K., Yadav, S.K., Diengdoh, L.C., Rai,R. and Bag,T.K. (2015) Effect of cultivars and seed size on field performance of potato microtubers in North Eastern Himalayan region in India. J. Appl. Nat. Sci., 7, 335-338.

Struik, P. (2007) The canon of potato science: 25 . Minitubers. Potato Res., 50, 305-308.

Struik, P. and Wiersema, S. (2012) "Seed Potato Technology". Wageningen Academic Publishers.

Struik, P. and Lommen, W.J.M. (1999) Improving the field performance of micro-and minitubers.Potato Res., 42, 559-568.

Wang, P. and Hu, C. (1982) In vitro mass tuberization and virus free seed potato production in Taiwan. Am. Potato J., 59, 33-37.

Wróbel, S. (2015) Assessment of potato microtuber and in vitro plantlet seedmultiplication in field conditions - Growth, development and yield. Field Crops Res., 178, 26-33.

Xu, X., Van Lammeren, A.A., Vermeer, E. and Vreugdenhil, D. (1998) The role of gibberellin, abscisic acid, and sucrose in the regulation of potato tuber formation in vitro. Plant Physiol., 117, 575-584. 


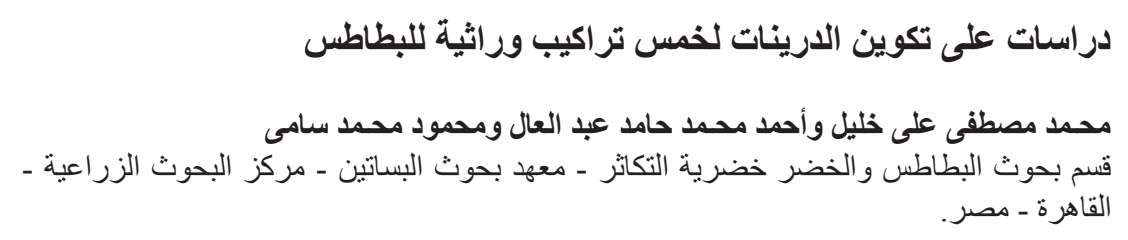

تمثل المواد الناتجة من مزارع الأنسجة الخطوة الأولى لبرامج إنتاج عالميا. تعتبر الدرينات أداة واعدة لعمل

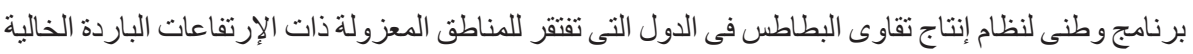

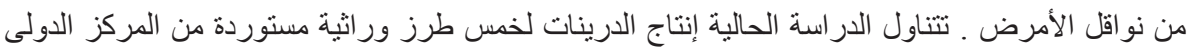
للبطاطس ببيرو مقارنة بالصنف دايمونت. دُرس تأثير إضافة عو امل تكوين الدرينات (80 جر ام سكروز أو لون

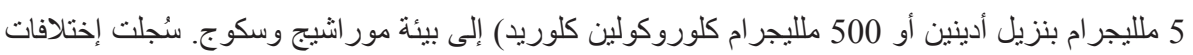

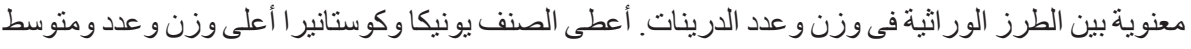

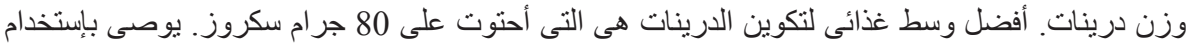
تركيز ات السكر المرتفعة لإنتاج درينات أصناف يونيكا وكوستانير ا ويلاكيزى وميفا.

كلمات مفتاحية : بطاطس ، تكوين الدرينات ، تر اكيب ور اثية ، المركز الدولى للبطاطس. 